\title{
PENGUATAN KULTUR SEKOLAH UNTUK MEWUJUDKAN PENDIDIKAN RAMAH ANAK
}

\author{
Wiwik Kusdaryani, Iin Purnamasari, dan Aries Tika Damayani \\ Fakultas Ilmu Pendidikan Universitas PGRI Semarang \\ Email: purnamaryo32@yahoo.com
}

\begin{abstract}
Abstrak: Penelitian bertujuan mengkaji konsep kultur sekolah, menganalisis konsep pendidikan ramah anak, dan penguatan kultur sekolah dalam mewujudkan pendidikan ramah anak. Jenis penelitian kualitatif dengan metode fenomenologi, yang dilakukan di SDN Pingit 01 Kecamatan Pringsurat Kabupaten Temanggung. Teknik pengumpulan data dilkukan dengan wawancara, pengamatan, dan analisis dokumen, sedang analisis data dengan teknik deskreptif kualitatif. Hasil penelitian menunjukkan bahwa: 1) konsep kultur sekolah meliputi beberapa modal budaya sekolah berdasarkan kebiasaan warga sekolah dan tertuang dalam visi misi, tata tertib, 8 budaya disiplin guru, dan 10 budaya malu siswa; 2) konsep pendidikan ramah anak ditemukan dalam sikap guru terhadap siswa yang memberikan perhatian, perlindungan, serta berperan sebagai informator, mediator, motivator dan fasilitator dalam meningkatkan prestasi akademik dan nonakademik, serta metode pembelajaran perlu ditingkatkan; 3) penguatan kultur sekolah dalam mewujudkan pendidikan ramah anak dikembangkan berdasarkan berbagai kebiasaan positif sekolah.
\end{abstract}

\section{Kata Kunci: kultur, sekolah, pendidikan ramah anak}

\section{STRENGTHENING THE SCHOOL CULTURE TO REALIZE THE CHILD-FRIENDLY EDUCATION}

\begin{abstract}
This study was aimed to examine the concept of the school culture, to analyze the child-friendly education, and to strengthen the school culture to realize the child-friendly education. This study used the phenomenology method, carried out ini SDN Pingit 01, Pringsurat, Temanggung. The data were collected using interviews, observations, and the document analysis. The data were analyzed using the qualitative descriptive analysis. The findings showed that: 1) the concept of school culture involved several school culture capitals based on the habit of the school members and this was conceptualized in the vision, mission, school regulations, 8 teachers' discipline cultural items, and 10 students' cultural items of being ashamed when doing something bad; 2) the concept of child-friendly education could be found in the teachers' attitude towards the students by giving attention and protection, by becoming informants, mediators, motivators, and facilitators to improve the students' academic and non-academic learning achievement; the teaching methods needed to be improved; 3) the strengthening of the school culture to realize the child-friendly education was developed based on several positive habits done in the school.
\end{abstract}

Keywords: culture, schools, child-friendly education

\section{PENDAHULUAN}

Sekolah selama ini telah dinilai sebagai lembaga pendidikan yang mapan dan mampu mencetak generasi yang akan menentukan masa depan bangsa. Sebagaimana diketahui, sekolah didefinisikan sebagai bangunan atau lembaga untuk belajar dan mengajar serta tempat menerima dan memberi pelajaran (Sunarto, 2004:76). Sekolah dipimpin seorang kepala sekolah, dan kepala sekolah dibantu oleh wakil kepala sekolah serta terdapat rancangan pengajaran untuk siswa di bawah pengawasan pendidik (guru). Sebagian besar negara memiliki sistem pendidikan sekolah sebagai perwujudan pendidikan di jalur formal, yang umumnya wajib sebagai upaya menciptakan anak didik agar mengalami kemajuan setelah proses pembelajaran. Pemberian nama untuk sekolah sangat beragam antarnegara namun 
secara umum sekolah dasar untuk anak-anak, dan sekolah menengah untuk remaja yang telah menyelesaikan pendidikan dasar.

Sekolah menyosialisasikan nilai-nilai yang hidup dalam masyarakat sehingga dipandang sebagai tempat yang menjadi transisi dari kehidupan keluarga ke dalam kehidupan masyarakat. Selanjutnya, seorang anak selama ini juga dipandang dapat belajar kemandirian lebih intensif di sekolah dibandingkan di tempat lain. Hal tersebut berkaitan dengan keyakinan masyarakat bahwa terdapat beberapa nilai yang ditanamkan sekolah yaitu, nilai kemandirian dan tanggungjawab anak sebagai peserta didik terhadap tugas dan pekerjaan yang diberikan. Nilai lain yang disosialisasikan adalah prestasi, dimana seorang anak dalam keluarga hanya diberikan peran secara taken for granted sejak lahir, namun di sekolah anak sebagai peeserta didik dipacu untuk berprestasi karena hal inilah yang akan menentukan posisi anak. Nilai universalisme sebagai wujud perlakuan sama pada setiap anak, tanpa memandang perbedaan status dan latar belakang sosial-ekonomi.

Terdapat nilai spesivisitas, yaitu anak di sekolah ditanggapi dan ditangani sesuai dengan apa yang dikerjakan, dimana hal tersebut berkebalikan dengan keberadaan anak di dalam keluarga yang dinilai kabur sebagai contoh saat terjadi kekeliruan/kelemahan dalam mata pelajaran tertentu di sekolah, anak akan dinilai lemah pada bidang tersebut dan belum tentu pada bidang yang lain. Secara lebih luas, sekolah dapat dikatakan mensosialisasikan nilai-nilai yang hidup dalam masyarakat secara berkesinambungan sebagai budaya/kultur yang dimiliki bersama.

Analisis sosial terhadap sekolah saat ini banyak mengupas konflik-konflik antarperanan yang terjadi di lembaga sekolah. Lembaga pendidikan sering dirasuki oleh nilai-nilai yang terkadang bertentangan antarpihak baik dari para guru, orangtua, staf birokrat, siswa maupun pihak aparat pimpinan sekolahsehingga dapat dianalisis mengenai keberadaan sekolah sebagai lembaga formal dalam aktifitas pendidikan melalui konsep organisasi sekolah.

Kompleksitas permasalahan dan pertentangan di sekolah merupakan derivasi dari perangkat-perangkat manusia yang memiliki beragam peran spesifik di lembaga sekolah. Banyak buku teks yang mengemukakan tentang peranan guru dan administrator yang harmonis dan serba sinergis. Padahal kenyataan membuktikan, salah satu faktor yang memberatkan kerja organisasi adalah gejala kesalahpahaman untuk memahami kawan sekerja berkenaan dengan hak dan kewajiban yang berbeda sesuai dengan status pekerjaan. Kecenderungan yang terjadi, hampir semua tanggung jawab dan tugas sekolah berhubungan dengan siswa selalu dilimpahkan kepada seorang pendidik.

Membahas tentang kultur sekolah tidak terlepas dari pengkajian tentang culture capital (modal budaya). Pada sisi sosiologis Pierre Bourdieu sebagai tokoh pemuka tentang modal budaya (Bourdieu, 1991:163), menyatakan bahwa modal budaya merupakan selera bernilai budaya dan pola konsumsi yang mencakup rentangan luas properti seperti seni, pendidikan dan bentuk-bentuk bahasa. Di sisi lain, juga dijelaskan bahwa batasan modal budaya sebagai berbagai pengetahuan yang sah. Penjelasan modal budaya secara lebih detail juga disampaikan oleh Lee (Damsar,2012:197), yaitu sebagai kepemilikan kompetensi kultural tertentu, atau seperangkat pengetahuan kultural yang menyediakan bentuk konsumsi kultural yang dibedakan secara khusus dan klasifikasi rumit dari barang-barang kultural dan simbolis.

Berdasarkan beberapa definisi di atas, dapat disimpulkan bahwa modal budaya merupakan kepemilikan kompetensi dan pengetahuan kultural yang menuntun selera bernilai budaya dan polapola konsumsi tertentu, yang dilembagakan dalam bentuk kualifikasi pendidikan. Dari pengertian tersebut tampak jelas bahwa pendidikan memberikan seseorang modal pengetahuan dan kompetensi yang dibutuhkan untuk membuat pembedaan atau penaksiran nilai. Nilai sopan santun, malu, kerja keras, kejujuran, kepercayaan, dan lain-lain yang dibentuk, diperkuat, dan dipertahankan terutama melalui pendidikan formal yaitu sekolah. Hal tersebut menunjukkan bagaimana nilai dan norma yang disosialisasikan oleh guru pada pendidikan dasar, sebagai rujukan berpikir, bersikap, dan berperilaku peserta didik. Nilai dan norma inilah yang menjadi mainstream dalam kehidupan bermasyarakat, dan dihubungkan melalui pendidikan salah satunya di lembaga sekolah. 
Sekolah sebagai organisasi sosial menurut Horton dan Hurt (1996:38-54), memiliki empat jenis sasaran yang salah satu diantaranya adalah sasaran ideologis. Pada sasaran ideologis bertalian dengan seperangkat sistem eksternal atau sistem nilai yang diyakini bersama. Dalam hal ini, nuansa budaya pada pengertian suatu sistem pengetahuan, gagasan, ide yang dimiliki suatu kelompok masyarakat yang berfungsi sebagai landasan pijak dan pedoman bagi masyarakat itu dalam bersikap dan berperilaku dalam lingkungan alam dan sosial sebagai tempat bernaung. Hal ini merupakan penjabaran dari pengaruh ideologis terhadap organisasi.

Sasaran ini menyoroti pengaruh interaktif kultural-ideologis yang dianut sebagaian manusia dalam menangkap, menyikapi, dan merespon eksistensi organisasi. Suatu bangsa umumnya memiliki semangat tinggi untuk meraih prestasi vertikal, sementara sekolah merupakan wadah yang cukup strategis bagi manusia untuk menopang ambisi mobilitas vertikalnya. Maka, dapat diasumsikan bahwa hampir sebagian warga sekolah maupun masyarakat akan mengarahkan keyakinan kultural tersebut dalam memaknai keberadaan sekolah (Astuti, 2012).

Pendidikan selama ini diketahui memiliki banyak definisi dari berbagai dimensi yang dikemukakan oleh para pakarnya. Dalam hal ini lebih spesifik yang perlu dibahas terkait dengan penelitian ini adalah pendidikan ramah anak. Sebagai proses belajar dalam kehidupan manusia, pendidikan yang senantiasa terjadi selama hidup dan sepaanjang hayat manusia hendaknya dilakukan dengan berbagai metode yang tepat agar diperoleh hasil yang optimal. Pendidikan adalah learning by doing, anak akan belajar dengan melakukan dan bukan hanya sekedar membayangkan. Pendidikan sebagai formasi, dimaksudkan bahwa semua pendidikan membentuk karakter, mental dan moral, namun pembentukan terdiri dari seleksi dan koordinasi kegiatan nyata sehingga anak dapat memanfaatkan subjek lingkungan sosial.

Selain itu, pembentukan terjadi melalui anak itu sendiri sebagai proses rekonstruksi, reorganisasi. Pendidikan sebagai rekapitulasi dan retrospeksi, individu mengembangkan, tetapi perkembangan tersebut dalam tahap yang teratur, berulang, sebagaimana evolusi kehidupan bina- tang dan sejarah manusia. Pembentuk rekapitulasi terjadi secara fisiologis yang harus dilakukan melalui pendidikan. Pendidikan sebagai rekonstruksi dimaksudkan bahwa rekonstruksi atau reorganisasi pengalaman yang menambahkan makna dari pengalaman, dan yang meningkatkan kemampuan langsung tentu merupakan pengalaman berikutnya.

Pengalaman manusia adalah hubungan antara manusia dengan masyarakat serta alam. Maka dapat dipahami bahwa John Dewey mengkonsepkan pendidikan sebagai alat bagi generasi muda untuk memperkenalkan kepada warisan budaya, namun bukan hanya sekedar untuk proses transmisi, tetapi juga kemungkinan untuk mengubah. Hal tersebut adalah prinsip utama pragmatisme yang menjiwai pendidikan baik di sekolah maupun di luar sekolah. Sekolah bukan sebagai lembaga yang memunyai tujuan tersendiri tetapi memunyai multitujuan sebagai lembaga sosial dan berhubungan dengan masyarakat di mana tujuan tersebut merupakan bagian di dalamnya. Sekolah juga merupakan suatu komunitas dan guru sekolah merupakan bagian dari masyarakat dan tidak terlepas dari kebudayaan serta masyarakat, maka pintu sekolah terbuka untuk masyarakat.

Pendidikan ramah anak sesuai dengan konsep di atas dapat dilakukan melalui lembaga pendidikan salah satunya adalah sekolah. Dalam hal ini dapat diformasikan dalam konsep Sekolah Ramah Anak (SRA). Pada konsep tersebut terdapat beberapa indikator yang dapat djadikan sebagai pijakan dalam pengembangannya. Beberapa indikator tersebut antara lain adalah: (a) inklusif secara proaktif, (b) sehat, aman, dan protektif, (c) partisipasi masyarakat, (d) efektif dan berpusat pada anak, (e) kesetaraan gender. Penerapan SRA memerlukan keterlibatan dan partisipasi semua pihak dalam mewujudkan suasana belajar dan proses Pembelajaran Aktif-Inovatif-KreatifEfektif-Menyenangkan (PAIKEM) untuk anak, guru dan warga sekolah lainnya.

Kultur sekolah yang berlandaskan pada hal-hal yang telah ditanamkan melalui nilai, norma, kepribadian anak, keyakinan, ideologis, visi-misi sekolah, keramahtamahan dalam sosialisasi, merupakan modal yang harus dijaga dan dikuatkan pengembangannya. Hal tersebut 
sangat beralasan karena dalam proses pembelajaran di sekolah yang merupakan bagian dari pelaksanaan pendidikan, anak membutuhkan pola hidup yang tertata, mengedepankan perlindungan, responsif terhadap kebutuhan anak atau yang disebut dengan istilah ramah anak. Budaya/ kultur yang terbangun berdasarkan pembiasaan kehidupan sekolah yang kondusif dan bermartabat serta senantiasa menempatkan anak sebagai mitra pendidikan merupakan upaya dalam memberikan provisi, proteksi dan partisipasi kepada anak untuk tumbuh dan berkembang dalam komunitas yaitu masyarakat sekolah. Pemberian kebebasan berekspresi, beraktivitas dan mengembangkan minat bakat anak penting untuk diwujudkan melalui berbagai metode dan media.

Metode yang digunakan dalam penguatan kultur sekolah diantaranya dapat dilakukan melalui penyampaian pesan-pesan moral yang mendukung terwujudnya visi dan misi yang menjadi landasan budaya sekolah. Adapun media yang digunakan dapat bervariasi dimulai dari pesan bergambar, pesan tertulis, ataupun media verbal melalui sosialisasi dari guru kepada siswa dalam berbagai kesempatan. Penguatan kultur sekolah harus dilakukan melalui berbagai cara oleh semua warga sekolah. Pesan-pesan moral yang responsif dan senantiasa mengingatkan pentingnya menjunjung tinggi hak anak di sekolah berlandaskan pada pola/budaya sekolah dapat disampaikan melalui pembuatan buku penghubung berdasarkan pada indikator budaya sekolah yang terdapat dalam visi misi, tata tertib, atau bisa juga berbagai hal yang terpola namun belum diatur secara tertulis dan masih bersifat konvensional di sekolah. Hal inilah yang dikembangkan dan menjadi inovasi dari penelitian ini.

\section{METODE}

Jenis penelitian yang digunakan adalah kualitatif dengan pendekatan fenomenologi, yang dilakukan selama 3 bulan dengan mengambil lokasi di SD Negeri Pingit 01 Kecamatan Pringsurat Kabupaten Temanggung Jawa Tengah. Subjek penelitian ini adalah siswa SD Negeri Pingit 01 Kecamatan Pringsurat Kabupaten Temanggung, yang meliputi seluruh warga sekolah beserta manajemen administrasi yang berkait dengan kultur sekolah.

Teknik pengumpulan data adalah wawancara, pengamatan, dan analisis dokumen. Adapun instrumen yang digunakan adalah peneliti sendiri sebagaimana menjadi ciri dari penelitian kualitatif. Instrumen pendukung berupa pedoman wawancara terstruktur dan tidak terstruktur, lembar observasi profil sekolah, lembar observasi interaksi anak, angket untuk guru, dan anak. Analisis dokumen dilakukan dengan mengumpulkan data-data terkait dokumen sekolah seperti profil sekolah, visi misi sekolah, tata tertib sekolah, jurnal kegiatan anak di sekolah. Uji keabsahan data dilakukan dengan cara perpanjangan pengamatan,

Tabel 1. Teknik Pengumpulan Data, Teknik Analisis Data, Uji Keabsahan Data dan Analisis Induktif

\begin{tabular}{|c|c|c|c|}
\hline $\begin{array}{c}\text { Teknik } \\
\text { Pengumpulan } \\
\text { Data }\end{array}$ & $\begin{array}{l}\text { Teknik dan Instrumen } \\
\text { Pengumpulan Data }\end{array}$ & $\begin{array}{c}\text { Uji Keabsahan } \\
\text { Data }\end{array}$ & Tahap Analisis Induktif \\
\hline Wawancara & $\begin{array}{l}\text { Pedoman wawancara } \\
\text { terstruktur dan tidak } \\
\text { terstruktur }\end{array}$ & \multirow{3}{*}{$\begin{array}{l}\text { Perpanjangan } \\
\text { pengamatan, } \\
\text { peningkatan } \\
\text { ketekunan dalam } \\
\text { penelitian, } \\
\text { tringulasi, diskusi } \\
\text { dengan teman } \\
\text { sejawat, dan } \\
\text { analisis kasus } \\
\text { negatif }\end{array}$} & $\begin{array}{l}\text { - Menyelidiki fenomena dan } \\
\text { menggambarkan kultur sekolah di } \\
\text { lokasi penelitian, }\end{array}$ \\
\hline Pengamatan & $\begin{array}{l}\text { Lembar observasi profil } \\
\text { sekolah, lembar } \\
\text { observasi guru dan anak, } \\
\text { lembar observasi pola } \\
\text { pembelajaran anak di } \\
\text { sekolah }\end{array}$ & & $\begin{array}{l}\text { Mengukur ciri-ciri kultur sekolah } \\
\text { dalam ragam situasi, } \\
\text { Menganalisis data kultur sekolah } \\
\text { yang dihasilkan untuk menentukan } \\
\text { pola-pola variasi yang sistematik } \\
\text { antara kultur sekolah dengan } \\
\text { pendidikan ramah anak }\end{array}$ \\
\hline $\begin{array}{l}\text { Analisis } \\
\text { Dokumen }\end{array}$ & $\begin{array}{l}\text { Pengumpulan data-data } \\
\text { terkait dokumen } \\
\text { sekolah, administrasi } \\
\text { anak didik, jurnal } \\
\text { pembelajaran anak }\end{array}$ & & $\begin{array}{l}\text { Membangun pemahaman baru } \\
\text { berdasarkan temuan di lapangan } \\
\text { tentang penguatan kultur sekolah } \\
\text { dalam mewujudkan pendidikan } \\
\text { ramah anak. }\end{array}$ \\
\hline
\end{tabular}




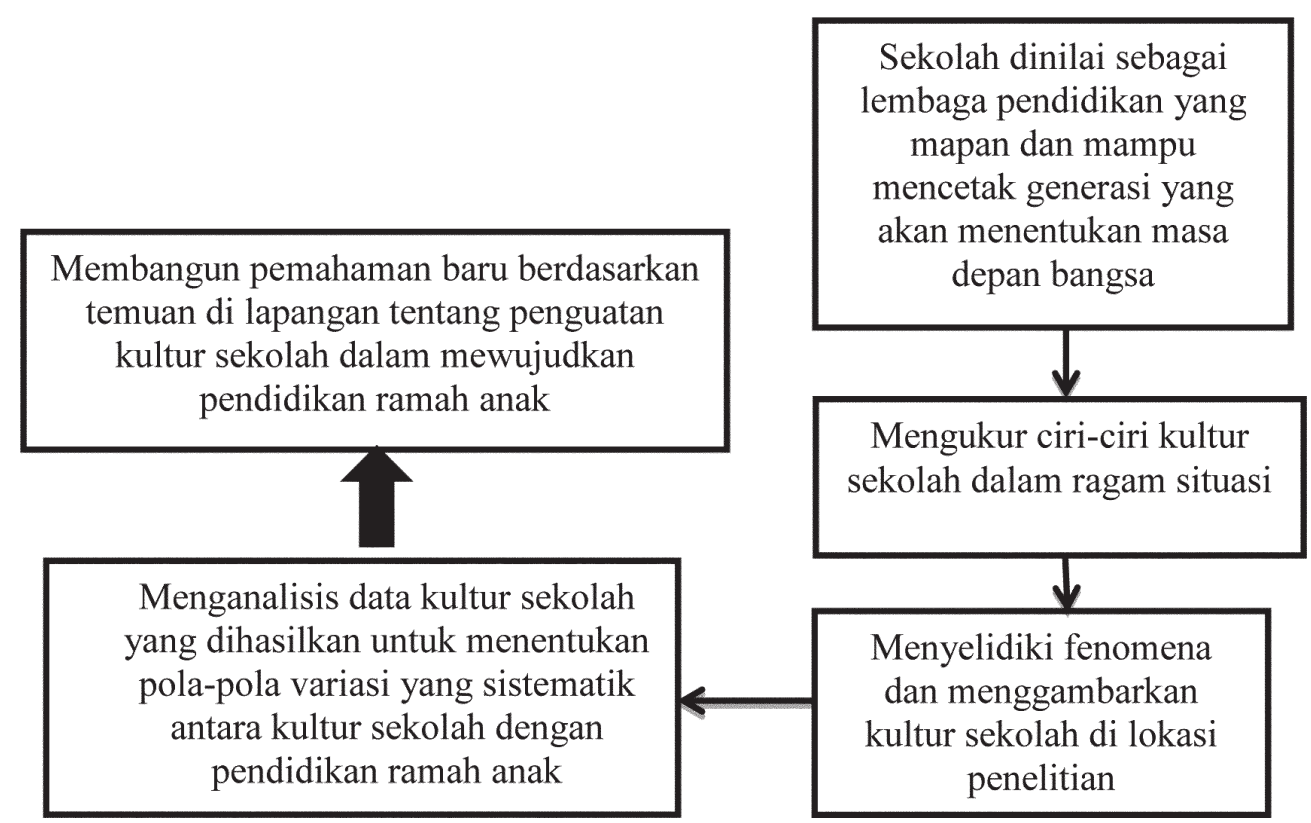

Gambar 1. Kerangka Konseptual Penelitian

peningkatan ketekunan dalam penelitian, tringulasi, diskusi dengan teman sejawat, dan analisis kasus negatif (Sugiyono, 2010:368).

Secara ringkas teknik pengumpulan data, teknik analisis data, uji keabsahan data, tahap analisis induktif fenomenologis ini disajikan dalam Tabel 1.

Pada Gambar 1 ditunjukkan bagan tahapan penelitian ini yang diawali dari kajian terhadap fenomena dan menggambarkan kultur sekolah di lokasi penelitian, mengukur ciri-ciri kultur sekolah dalam ragam situasi, menganalisis data kultur sekolah yang dihasilkan untuk menentukan pola-pola variasi yang sistematik antara kultur sekolah dengan pendidikan ramah anak, dan membangun pemahaman baru berdasarkan temuan di lapangan tentang penguatan kultur sekolah dalam mewujudkan pendidikan ramah anak.

\section{HASIL DAN PEMBAHASAN}

SD Negeri Pingit 01 merupakan dasar negeri yang terletak di Dusun Krajan Desa Pingit Kecamatan Pringsurat Kabupaten Temanggung. Visi sekolah adalah unggul dalam prestasi berdasarkan kedisiplinan, iman dan taqwa.

Misi sekolah adalah: (1) melaksanakan pembelajaran dan bimbingan secara efektif untuk mengoptimalkan potensi yang dimiliki siswa; (2) menumbuhkembangkan penghayatan dan pengamalan terhadap agama yang dianut untuk membentuk budi pekerti yang luhur; (3) menciptakan suasana yang aman dan menyenangkan untuk keefektifan seluruh kegiatan sekolah; (4) mengembangkan budaya kompetitif bagi siswa dalam upaya peningkatan prestasi; (5) meningkatkan kedisiplinan dan mengutamakan kerjasama dalam menyelesaikan tugas kependidikan; (6) melestarikan dan mengembangkan olahraga, seni, dan budaya; (7) mengembangkan pribadi yang cinta tanah air. Visi dan misi sekolah merupakan cerminan dan rumusan indikator kultur yang terbangun. Budaya yang ada di sekolah menjadi modal yang dapat dijadikan sebagai landasan dalam menguatkan pola pendidikan yang dicitacitakan, termasuk dalam mengembangkan pendidikan ramah anak.

Tata Tertib berlaku selama anak di luar sekolah adalah: (1) siswa wajib menjaga nama baik sekolah, di mana pun berada; (2) siswa wajib berperilaku sopan dan susila kepada orang lain; (3) siswa wajib minta izin kepada orangtua, jika akan berangkat ke sekolah. Tata tertib di sekolah antara lain: (1) siswa harus sudah hadir di sekolah 10 menit sebelum pelajaran dimulai; (2) siswa yang hadir terlambat harus minta izin kepada guru/wali kelas ketika akan masuk ke kelas mengikuti pelajaran; (3) siswa tidak diperbolehkan meninggalkan kelas/sekolah, sebelum jam pelajaran berakhir; (4) siswa yang akan meninggalkan kelas/pelajaran, harus minta izin 
guru kelas/wali kelas/guru piket; (5) siswa yang akan berhalangan hadir/tidak masuk sekolah, dengan dalih apapun harus minta izin kepada guru kelas/wali kelas, dengan surat izin dari orangtua/ wali siswa; (6) pada saat jam istirahat, siswa tidak diperbolehkan berada dalam kelas, kecuali ada hal-hal khusus (misal hujan); (7) pada saat istirahat tidak diperkenankan keluar dari lokasi sekolah, apabila akan keluar dari lokasi sekolah karena ada kepentingan harus izin kepada guru kelas/piket; (8) siswa tidak diperbolehkan jajan sembarangan.

Pada bidang Kebersihan/Kesehatan siswa diatur sebagai berikut. (1) Siswa ikut bertanggungjawab atas kebersihan dan keindahan sekolah dan kelas masing-masing serta membuang sampah pada tempat sampah. (2) Siswa yang sedang menderita penyakit menular, dianjurkan untuk tidak masuk sekolah sampai sembuh penyakitnya. (3) Siswa dilarang keras merokok di dalam kelas maupun di luar sekolah. Tata tertib yang berkaitan dengan pakaian adalah: (1) siswa wajib memakai pakaian seragam sekolah sebagai berikut, pada hari: Senin dan Selasa: Seragam Merah Putih, Topi Merah. Rabu dan Kamis: Batik, Jumat dan Sabtu: Pramuka; (2) siswa wajib bersepatu hitam kaos kaki putih, dilarang memakai sepatu sandal. Pada bidang Keamanan tata tertibnya adalah: (1) siswa ikut bertanggungjawab atas keamanan dan ketertiban sekolah; (2) siswa dilarang keras membawa senjata tajam; (3) pelanggaran terhadap tata tertib akan dikenai sanksi.

Tata tertib di sekolah tidak hanya berlaku bagi siswa, namun terdapat pula tata tertib yang berlaku bagi guru. Tata tertib tersebut di samping mengikuti kaidah peraturan bagi Pegawai Negeri Sipil dan beberapa aturan kepegawaian yang ditentukan oleh Pemerintah Daerah Kabupaten Temanggung, juga ditentukan sendiri oleh sekolah. Hal tersebut terlihat dalam 8 Disiplin yang disusun oleh sekolah sebagai berikut: $\boldsymbol{D}$, Datang Tepat Pada Waktunya. I, Isi Daftar Hadir. $\boldsymbol{S}$, Siapkan Sarana Kerja yang Sebaik-baiknya. I, Isi Jam-Jam Kerja dengan Kegiatan Sesuai dengan Tanggung Jawanya. $\boldsymbol{P}$, Patuhi Semua Peraturan yang Berkaitan dengan Tugas. $\boldsymbol{L}$, Laksanakan Tugas yang Menjadi Kewajiban Sesuai dengan Kewenangan. I, Izin Apabila Tidak Hadir/Tidak Dapat Melaksanakan Tugas dan atau Meninggal- kan Kantor. $\boldsymbol{N}$, Norma-Norma Kepegawaian dan Kesadaran yang Tinggi Harus Selalu Menjiwai.

Hal lain yang ditumbuhkembangkan sebagai kultur sekolah adalah adanya budaya malu yang ditanamkan, dan tertuang dalam 10 Budaya Malu sebagai berikut: (1) Aku Malu Terlambat Sekolah. (2) Aku Malu Melanggar Peraturan. (3) Aku Malu Sering Tidak Masuk Sekolah/Bolos. (4) Aku Malu Menangis Di Waktu Sekolah. (5) Aku Malu Tidak Memakai Seragam Sekolah yang Sudah Ditentukan atau Tidak Rapi. (6) Aku Malu Malas Belajar. (7) Aku Malu Mengganggu Aktifitas Teman. (8) Aku Malu Jahat Sama Teman-Teman. (9) Aku Malu Ngompol Di Waktu Sekolah. (10) Aku Malu Melihat Teman Pintar.

Berdasarkan pada visi misi yang telah dirumuskan, dapat dikatakan bahwa sekolah tersebut memiliki kultur yang telah terbentuk dan berjalan. Sebagaimana tertera dalam visi sekolah, yaitu unggul dalam prestasi berdasarkan kedisiplinan, iman dan taqwa. Terbentuknya kultur sekolah diantaranya berlandaskan pada nilai-nilai yang tertuang dalam visi misi, tata tertib serta hal-hal yang telah berjalan sebagai kebiasaan di sekolah tersebut.

Kultur unggul dalam prestasi, dilaksanakan dengan berbagai upaya antara lain melaksanakan pembelajaran dan bimbingan secara efektif untuk mengoptimalkan potensi yang dimiliki siswa, mengembangkan budaya kompetitif bagi siswa dalam upaya peningkatan prestasi, melestarikan dan mengembangkan olahraga, seni, dan budaya. disamping itu juga diupayakan menciptakan suasana yang aman dan menyenangkan untuk keefektifan seluruh kegiatan sekolah. Peningkatan prestasi yang maksimal baik di bidang intra maupun ekstrakurikuler dilakukan dalam rangka menghantarkan siswa untuk mengoptimalkan proses pembelajaran dengan pendekatan pembelajaran yang berpusat pada siswa serta layanan bimbingan dan konseling.

Hal lain yang dilakukan adalah meraih kejuaraan dalam bidang siswa berprestasi baik pada aspek Mata Pelajaran (Lomba MAPEL dan MAPSI (Olah Raga dan Seni). Pelestarian budaya daerah melalui Mulok Bahasa Jawa dengan indikator $85 \%$ siswa mampu berbahasa Jawa sesuai dengan konteks. Prestasi lain yang hendak diraih dan menjadi salah satu tujuan adalah menjadikan 
90\% siswa memiliki kesadaran terhadap kelestarian lingkungan hidup di sekitarnya, serta meraih kejuaraan dalam beberapa cabang olahraga di tingkat propinsi Jawa Tengah.

Kultur disiplin, terlihat dalam beberapa aspek seperti: mengembangkan pribadi yang cinta tanah air, serta meningkatkan kedisiplinan dan mengutamakan kerjasama dalam menyelesaikan tugas kependidikan. Bagi guru, kultur disiplin selain melaksanakan tugas sesuai aturan dari Pemerintah Daerah Kabupaten Temanggung dan sebagaimana tugas, pokok dan fungsi Pegawai Negeri Sipil, juga melakssanakan hal-hal yang disepakati nilai-nilai disiplin yang diberlakukan oleh sekolah, yang tertuang dalam 8 disiplin. Bagi siswa, nilai-nilai kedisplinan diwujudkan dengan pelaksanaan tata tertib siswa yang diharapkan dapat tertanam dengan dipajangnya tata tertib tersebut pada setiap kelas. Tentang internalisasi sikap disiplin telah dilakukan penelitian oleh Wuryandari dkk (2014).

Selain itu, terdapat pembiasaan-pembiasaan bagi siswa yang dituangkan dalam 10 budaya malu yang dipajang pada tempat-tempat strategis baik di dalam maupun di luar kelas. Budaya malu tersebut menjadi nilai-nilai yang dijunjung tinggi dan menjadi modal budaya bagi masyarakat dan siswa. Pembentukan jiwa cinta tanah air juga dapat membentuk kedisplinan yang direalisasikan melalui kegiatan upacara bendera setiap har Senin dan Hari Besar Nasional, serta pelaksanaan kegiatan Pramuka yang menjadi ekstrakurikuler wajib dimulai dari tingkat Siaga sampai dengan Penggalang.

Kultur iman dan taqwa, dilakukan dengan menumbuhkembangkan penghayatan dan pengamalan terhadap agama yang dianut untuk membentuk budi pekerti yang luhur. Peningkatan kuantitas kegiatan agamis dilakukan hampir setiap hari selama satu minggu yang meliputi bacaan asmaul husna bagi siswa muslim setiap pagi, doa pagi bagi siswa non muslim setiap pagi (sebelum pelajaran dimulai), sholat berjamaah, santapan rohani dan berlatih infaq di setiap hari jumat untuk meningkatkan iman dan taqwa.

Pengaturan sistem belajar di samping mengikuti alokasi waktu yang disesuaikan dengan struktur KTSP, juga dilaksanakan dengan pemberian mata pelajaran Mulok (Muatan Lokal). Hal ini berkaitan dengan pendidikan multi kultur sebagai kegiatan kurikuler untuk mengembangkan kompetensi kearifan lokal dalam upaya hidup bersama dalam keanekaragaman budaya, suku, agama, dan menanamkan kecintaan siswa terhadap lingkungan dan konsisten sekitar termasuk keunggulan lain di sekitar sekolah. Adapun muatan lokal yang dipilih adalah Bahasa Jawa sebagai mulok wajib propinsi, pendalaman kitab suci sebagai mulok wajib kabupaten, dan Bahasa Inggris sebagai mulok wajib.

Pengembangan diri juga diberikan dalam rangka memberikan kesempatan kepada siswa untuk mengembangkan dan mengekspresikan diri sesuai dengan kebutuhan, minat dan bakat siswa sesuai dengan kondisi sekolah. Kegiatan pengembangan diri difasilitasi dan atau dibimbing oleh konselor, guru atau tenaga kependidikan yang dapat dilakukan dalam bentuk ekstrakurikuler. Berdasarkan kondisi objektif sekolah kegiatan pengembangan diri yang dipilih dan ditetapkan sekolah adalah Teknologi Informatika dan Komunikasi (TIKOM), Pramuka, Drumband, Taman Pendidikan Al Quran (TPQ), Sepakbola atletik, Voli Mini dan dokter kecil.

Sebagaimana telah dikonsepkan dalam pendidikan ramah anak bahwa terdapat beberapa hal yang berkaitan dengan hak-hak anak. Pelaksanaan pendidikan telah menunjukkan adanya penanaman dan pelaksanaan konsep pendidikan ramah anak khususnya untuk sekolah. Hal tersebut ditunjukkan dalam beberapa hal sebagaimana menjadi temuan dalam penelitian ini berkaitan dengan tiga indikator pendidikan ramah anak.

(1) Sikap guru terhadap anak, kasih sayang terhadap semua anak, menerapkan norma-norma agama dan budaya yang berlaku tercermin dalam kebiasaan guru yang telah siap hadir 15 menit sebelum pelajaran dimulai setiap pagi, melaksanakan jabat tangan pagi dan mengarahkan siswa untuk melaksanakan doa bersama sesuai dengan agama dan kepercayaan masing-masing sebagaimana menjadi tata tertib sekolah. Hal tersebut menunjukkan bahwa sekolah menjunjung tinggi norma-norma agama dan budaya secara berdampingan secara adil dan tanpa membedakan perbedaan yang ada termasuk dalam berdoa disesuaikan dengan agama yang dianut oleh siswa, dan tetap diberikan kesempatan yang sama untuk melaksanakannya. 
(2) Metode Pembelajaran, guru menerapkan beberapa metode dalam pembelajaran seperti ceramah, diskusi, tanya jawab, kerjasama, demonstrasi, penugasan dan lain-lain dengan menyesuaikan materi pembelajaran atau kegiatan yang dilakukan. Namun, penggunaan metode pembelajaran tersebut masih banyak didominasi oleh metode konvensional, dan baru di kelas rendah (1 sampai dengan 3) yang banyak menggunakan metode bervariasi, karena melaksanakan pembelajaran tematik. Sehingga selain metode pembelajarannya maka media yang digunakan pun juga bervariasi. Guru di kelas 1 sampai dengan kelas 3 lebih banyak menggunakan alat peraga sederhana yang kebanyakan adalah hasil karya siswa. Penerapan metode dan pemanfaatan media ini diharapkan dapat menciptakan suasana pembelajaran berbasis pengalaman dan menyenangkan bagi siswa.

(3) Ruang lingkup kelas, telah banyak diuraikan di atas bahwa ruang kelas harus benar-benar mendukung gerak anak. Penggunaan bangku dan kursi harus sesuai ukuran dan kenyamanan anak. Begitu juga pemilihan warna cat sebisa mungkin sesuai warna anak, cerah dan menyenangkan sehingga dapat merasa senang berada di kelas, tidak lekas bosan. Namun, hal tersebut belum dilakukan, terlihat bahwa penataan bangku, pilihan warna kelas dan posisi tempat duduk siswa masih mengikuti model konvensional dan belum variatif. Hal ini menunjukkan siswa belum dilibatkan secara penuh dalam penataan kelas, serta belum diberikan kesempatan dalam menyampaikan gagasan dalam hal mengatur ruang belajarnya. Memasang hasil karya, majalah dinding dan lain-lain masih menjadi kewenangan guru. Hal yang tidak kalah penting adalah sanitasi higienis. Tersedianya sarana MCK juga sangat penting untuk melatih anak hidup bersih dan sehat. Dalam hal ini peneliti menemukan bahwa sarana MCK, sanitasi higienis telah tersedia di sekolah, namun yang perlu dipertimbangkan lagi untuk pelaksanaan pendidikan ramah anak adalah penyediaan Kamar Mandi/KM dan WC bagi siswa putra dan putri secara terpisah serta KM/ WC bapak dan ibu guru yang terpisah juga. Hal tersebut berkaitan dengan karakteristik ramah dan responsif gender.
Uraian di atas menunjukkan bahwa pendidikan di SDN 01 Pingit dalam beberapa aspek telah menunjukkan adanya konsep pendidikan ramah anak berdasarkan Pasal 4 UU No.23 Tahun 2002 tentang Perlindungan Anak, dan dalam beberapa hal patut menjadikan pertimbangan jika hendak dilakukan rintisan sebagai Sekolah Ramah Anak (SRA) berdasarkan konsep dan karakteristik SRA. Dimana dalam konsep tersebut terdapat beberapa indikator yang dapat djadikan sebagai pijakan dalam pengembangannya. Beberapa indikator tersebut antara lain; (a) inklusif secara proaktif, (b) sehat, aman, dan protektif, (c) partisipasi masyarakat, (d) efektif dan berpusat pada anak, (e) kesetaraan gender. Perlu disampaikan bahwa berdasarkan analisis penelitian ini memiliki beberapa indikator di atas, dan masih perlu menambahkan pada beberapa aspek yang lain.

\section{SIMPULAN}

Berdasarkan hasil penelitian, pembahasan dan uraian di atas dapat disimpulkan beberapa hal sebagai berikut.

1. Konsep kultur sekolah di SDN 01 Pingit Kecamatan Pringsurat Kabupaten Temanggung, meliputi beberapa modal budaya yang telah dimiliki dan ditanamkan oleh sekolah tersebut dan dilaksanakan sebagai kebiasaan warga sekolah yang tertuang dalam visi misi, tata tertib sekolah, 8 budaya disiplin bagi guru, dan 10 budaya malu bagi siswa.

2. Konsep pendidikan ramah anak menunjukkan bahwa dalam beberapa aspek, yaitu sikap guru terhadap siswa yang memberikan perhatian, perlindungan, dan berperan sebagai informator, mediator, motivator dan fasilitator dalam meningkatkan prestasi akademik maupun non akademik siswa. Aspek metode pembelajaran yang perlu untuk ditingkatkan karena masih didominasi dengan menggunakan metode dan media konvensional.

3. Penguatan kultur sekolah dalam mewujudkan pendidikan ramah anak dapat dikembangkan lebih lanjut berdasarkan berbagai kebiasaan positif yang telah membudaya menuju terbentuknya Sekolah Ramah Anak (SRA). 


\section{UCAPAN TERIMA KASIH}

Ucapan terima kasih penulis sampaikan kepada Dr. Muhdi, S.H., M.Hum. selaku Rektor Universitas PGRI Semarang; Drs. Agus Suharno M.Si. selaku Dekan FIP Universitas PGRI Semarang; Kepala Sekolah SDN 01 Pingit Kecamatan Pringsurat Kabupaten Temanggung, dan semua pihak yang telah membantu pelaksanaan penelitian ini.

\section{DAFTAR PUSTAKA}

Astuti, Siti Irene. 2012. "Dinamika Struktur dan Kultur dalam Penerapan Desentralisasi Pendidikan", dalam Cakrawala Pendidikan, XXXI (Edisi Khusus Dies Natalis UNY), hlm. 125-141.

Bourdieu, Piere. 1991. Language and Symbolic Power. Great Britain: T.J Press Ltd. Padstow, Cornwall.

Damsar. 2012. Pengantar Sosiologi Pendidikan, Jakarta: Kencana Prenada Media Group.

Horton, Paul B \& Chester L. Hunt. 1996. Sociology. Alih Bahasa Amiruddin Ram. Jakarta: Erlangga.
Kurikulum Tingkat Satuan Pendidikan (KTSP) Tahun Pelajaran 2014/2015. SDN 01 Pingit. UPT Dinas Pendidikan dan Kebudayaan Kecamatan Pringsurat Kabupaten Temanggung.

Sugiyono. 2012. Metode Penelitian Pendidikan: Pendekatan Kuantitatif, Kualitatif dan $R \& D$. Bandung: Alfabeta.

Sunarto, Kamanto. 2004. Pengantar Sosiologi (Edisi Revisi). Jakarta: Lembaga Penerbitan Fakultas Ekonomi Universitas Indonesia.

Wuryandani, Wuri, Bunyamin Maftuh, Sapiya, \& Damin Budimansyah. 2014. "Internalisasi Nilai Karakter Disiplin melalui Penciptaan Iklim Kelas yang Kondusif di SD Muhammadiyah Sapen Yogyakarta", Jurnal Pendidikan Karakter, Th IV, No. 3, hlm. 175-184. 